2 Barkun JS, Barkun AN, Sampalis JS, Field G, Taylor B, Wexler MJ, et al. Randomised controlled trial of laparoscopic versus mini cholecystectomy. Lancet 1992;340:1116-9.

McMahon AJ, Russell IT, Baxter JN, Ross SJ, Anderson JR, Morran CG, et al. Laparoscopic versus minilaparotomy cholecystectomy: a randomised trial. Lancet 1994;343:135-8.

4 McGinn FP, Miles AJG, Uglow M, Ozmen M, Terzi C, Humby M. Randomised trial of laparoscopic cholecystectomy and mini-cholecystectomy. Br f Surg 1995;82:1374-7.

5 McMahon AJ, Russell IT, Ramsey G, Sunderland GT, Baxter JN, Anderson JR, et al. Laparoscopic and minilaparotomy cholecystectomy: a randomised trial comparing postoperative pain and pulmonary function. Surgery 1994;115:533-9.

6 Pocock SJ. Clinical trials: a practical approach. Chichester: Wiley, 1983.

7 Stirrat GM, Farndon J, Farrow SC, Dwyer N. The challenge of evaluating surgical procedures. Ann R Coll Surg Engl 1992;74:80-4.

8 McMahon AJ, Ross SJ, Baxter JN, Russell IT, Morran CG, Sunderland GT, et al. Symptomatic outcome one year after laparoscopic and minilaparotomy cholecystectomy: a randomised trial. Brf Surg 1995;82:1378-82.

9 NHS Research and Development Task Force. Supporting research and development in the NHS London: HMSO, 1994.

10 Pinion SB, Parkin DE, Abramovich DR, Naji AA, Alexander DA, Russell IT, et al. Randomised trial of hysterectomy, endometrial laser ablation and transcervical endometrial resection for dysfunctional uterine bleeding. $B M F$ 1994;309:979-83.

11 Henshaw RC, Naji SA, Russell IT, Templeton AA. Comparison of medical abortion with surgical vacuum aspiration: women s preferences and acceptability of treatment. BMF 1993;307:714-8. 12 Zelen M. A new design for randomised clinical trials. NEngl f Med 1979;300:1242-5.

13 Schwartz D, Lellouch J. Explanatory and pragmatic attitudes in clinical trials. $f$ Chronic Dis 1967;20:637-48.

14 Russell IT. Clinical trials and evaluation of surgical procedures. Surgery 1984:196-9.

\title{
Corticosteroids in the management of croup
}

\author{
Nebulised corticosteroids are the treatment of choice
}

Although croup is one of the commonest childhood complaints, its treatment has been empirical at best. Traditional management at home consists of creating a warm moist atmosphere by placing the child in a steam filled bathroom with the hot water taps running, but there is no objective evidence that this treatment is effective. Nebulised adrenaline is commonly prescribed in North America, and although it is of proved benefit, its effect is short lived. ${ }^{1}$ Corticosteroids have been advocated, but until recently their use was contentious because of conflicting reports. ${ }^{2-4}$

Croup, or laryngotracheobronchitis, is most commonly seen in children aged 6 months to 4 years. It is caused by viral infection, usually with parainfluenza virus, although infection with influenza, respiratory syncitial virus, or rhinovirus may cause a similar clinical picture. Croup is characterised by a harsh, barking, seal-like cough, stridor, and hoarse voice, with symptoms usually occurring at night. There is usually a preceding coryzal illness, but fever rarely exceeds $39^{\circ} \mathrm{C}$. The three most important differential diagnoses are epiglottitis, bacterial tracheitis, and inhalation of a foreign body. Epiglottitis is rare since the introduction of widespread immunisation against Haemophilus influenzae, and it virtually never results in a barking cough. This leaves bacterial tracheitis as the most important differential diagnosis. Although cough is a prominent feature, it is rarely barking, and the child is usually unwell.

The value of corticosteroids in the management of croup has recently been reappraised..$^{5-7}$ A meta-analysis of randomised controlled trials suggested that oral corticosteroids reduced the need for endotracheal intubation in children with severe croup, ${ }^{6}$ and a prospective study has shown that oral corticosteroids result in earlier extubation and less frequent reintubation in children who have been intubated. ${ }^{7}$ More important have been reports of the beneficial effects of nebulised corticosteroids in mild to moderate croup. In a randomised trial in 36 infants admitted with croup Husby et al reported significant improvement in those treated with $2 \mathrm{mg}$ of nebulised budesonide compared with those treated with placebo. ${ }^{8}$ The researchers graded the severity of croup with a standardised clinical scoring system (maximum score 15) based on the degree of stridor, cough, chest retraction, dyspnoea, and skin discoloration. The croup score decreased significantly from a mean of 8 to 4.5 in the children who received budesonide, while it remained at 8 before and after treatment in the children who received nebulised saline. The fact that significant improvement was evident within two hours suggests more than a simple anti-inflammatory effect.

Using a slightly different croup score, Klassen et al measured the effect of nebulised budesonide in 54 children with mild to moderate croup who attended an emergency department. ${ }^{9}$ Four hours after treatment the mean croup score was significantly lower in children who received budesonide compared with those who received placebo. More importantly, children who received budesonide were discharged from the emergency department earlier and only one child required admission to hospital, compared with seven of the children who received placebo. In a further comparison of either $2 \mathrm{mg}$ of nebulised budesonide or $0.6 \mathrm{mg} / \mathrm{kg}$ of oral dexamethasone versus placebo in children admitted to hospital for croup those who received either nebulised budesonide or oral dexamethasone showed a faster decrease in the croup score and were less likely still to be in hospital 24 hours later. ${ }^{10}$

Croup scores are a relatively crude and subjective measure of severity. Evidence of improvements in more objective physiological measures, such as shift in the phase relation between movement of the ribcage and abdomen, would be welcome. Taken together, however, these studies suggest that corticosteroids are effective in croup. Nebulised corticosteroids probably have fewer side effects than systemic corticosteroids, although there have been no direct comparisons, and they would therefore seem to be the treatment of choice in mild to moderate croup. Although they have been shown to decrease the risk of admission to hospital from an emergency department, there is still a need for controlled studies in the community showing a similar effect. Nevertheless, nebulised budesonide has the potential to decrease hospital admissions for croup, and general practitioners may find it a useful emergency drug to carry. Oral prednisolone may prove to be an alternative. It is essential that the child is reassessed two to four hours after treatment. Failure to respond to treatment should raise the need for alternative diagnoses and admission to hospital.

IOLO DOULL

Senior registrar in paediatric intensive care

Great Ormond Street Hospital for

Children NHS Trust,

Institute of Child Health,

London WC1N 3JH

1 Skolnik NS. Treatment of croup: a critical review. Am F Dis Child 1989;143:1045-9.

2 Martensson B, Nilsson G, Torbjar JE. The effects of corticosteroids in the treatment of pseudocroup. Acta Otolaryngol Suppl 1968;158:62-71.

3 Kuusela AL, Vesikari T. A randomised double blind, placebo controlled trial of dexamethasone and racemic epinephrine in the treatment of croup. Acta Paediatr Scand 1988;77:99-104.

4 Super DM, Cartelli NA, Brooks LJ, Lembo RM, Kumar ML. A prospective randomised double blind study to evaluate the effect of dexamethasone in acute laryngotracheitis. $f$ Pediatr 1989;115:323-39.

5 Landau LI, Geelhoed GC. Aerolized steroids for croup. N Engl f Med 1994;331:322-3.

6 Kairys SW, Olmstead EM, O'Connor GT. Steroid treatment of laryngotracheitis: a metanalysis of the evidence from randomised trials. Pediatrics 1989;83:683-93.

7 Tibballs J, Shann FA, Landau LI. Placebo controlled trial of prednisolone in children intubated for croup. Lancet 1992;340:745-8.

8 Husby S, Agertoft L, Mortensen S, Pedersen S. Treatment of croup with nebulised steroid (budesonide): a double blind, placebo controlled study. Arch Dis Child 1993:68:352-5.

9 Klassen TP, Feldman ME, Watters LK, Sutcliffe T, Rowe PC. Nebulised budesonide for children with mild to moderate croup. N Engl F Med 1994;331:285-9.

10 Geelhoed GC, Macdonald WBS. Comparison of oral and inhaled steroids in the treatment of croup [abstract]. Am $\mathcal{G}$ Resp Crit Care 1994;149:A375. 